Note

\section{Synthesis of a Lactam Analog of AM-Toxin I}

\section{Toshiro Kozono, Tatsuhiko Kanmera, Tetsuo Kato, Tamio UENo* and Nobuo IzUmiYA}

\author{
Laboratory of Biochemistry, Faculty of Science, \\ Kyushu University, Higashi-ku, \\ Fukuoka 812, Japan \\ *Pesticide Research Institute, \\ College of Agriculture, \\ Kyoto University, Sakyo-ku, \\ Kyoto 606, Japan
}

Received February 15, 1983

AM-toxins are host-specific phytotoxic metabolites produced by Alternaria mali, which cause leaf spot disease in apple. ${ }^{1)}$ AM-toxin I has the structure shown in Fig. 1, and AM-toxins II and III have similar structures, but instead of L-2-amino-5-( $p$-methoxyphenyl)-pentanoic acid (LAmp) in I, AM-toxins II and III contain L-2-amino-5phenylpentanoic and L-2-amino-5-(p-hydroxyphenyl)pentanoic acid, respectively. We have previously synthesized AM-toxins I, II, III, and their analogs and determined necrotic activities on apple leaf with these toxins. ${ }^{2 \sim 4)}$ A characteristic feature of the structure of AM-toxins is the occurrence of a lactone bond in their cyclic back-

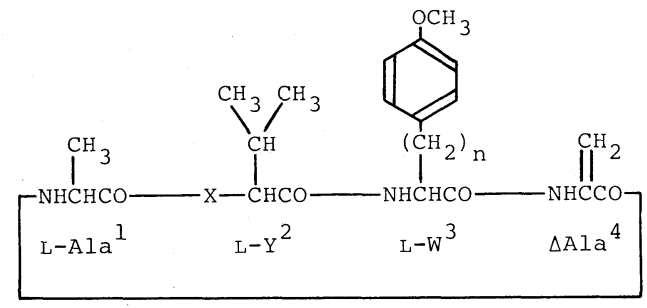

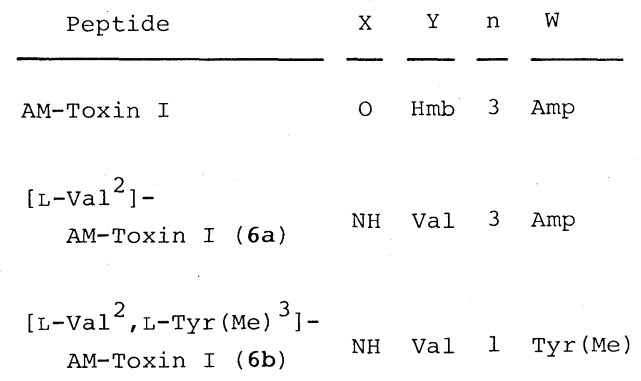

FIG 1. Structures of AM-Toxin I and Its Lactam Analogs. bone. Other phytotoxic cyclic tetrapeptides such as tentoxin $^{5)}$ and chlamydocin ${ }^{6)}$ are exclusively composed of lactam linkages. Therefore, we tried to synthesize AMtoxin I analogs containing $\mathrm{L}$-valine in place of $\mathrm{L}-2$ hydroxy-3-methylbutanoic acid (L-Hmb). As the minimum toxic concentrations of AM-toxins I, II and III were reported to be $0.002,0.02$, and $0.02 \mu \mathrm{g} / \mathrm{ml}$, respectively, we tried to synthesize a lactam analog of the most toxic AM-toxin I and to evaluate the effect of substitution of an amide bond for an ester bond in AMtoxins.

Synthesis of peptides. As a preliminary study for synthesizing the desired $\left[\mathrm{L}-\mathrm{Val}^{2}\right]-\mathrm{AM}$-toxin I (6a), a simplified analog, cyclo-L-Ala $\left.{ }^{1}-\mathrm{L}-\mathrm{Val}^{2}-\mathrm{L}-\mathrm{Try}(\mathrm{Me})^{3}-\Delta \mathrm{Ala}^{4}-\right)(6 \mathbf{b})$, was prepared, because $O$-methyl-L-tyrosine (L-Tyr(Me)) was easily derived by the methylation of L-tyrosine. To prepare the $\Delta$ Ala residue, we used the Hofmann degradation of D-2,3-diaminopropionic acid (D-Dap) according to the successful synthesis of AM-toxin III. ${ }^{4)}$ In order to obtain a cyclic monomer in good yield at the cyclization step, the D-amino acid residue was placed at the $N$-terminus of a cyclization precursor, because in the case of the AMtoxin III synthesis, cyclization of the precursor having a $\beta$-benzyloxycarbonyl-D-Dap (D-Dap $(Z))$ residue at the $\mathrm{N}$-terminus yielded the cyclic monomer exclusively. ${ }^{4}$ ) Boc-D-Dap (Z)-L-Ala-L-Val-L-Tyr(Me)-OH (1b) was prepared by stepwise elongation from L-Tyr(Me) toward the amino end using Boc-amino acid $N$-hydroxysuccinimide (HONSu) ester and following by removal of the Boc-group with $\mathrm{HCl}$ in dioxane. Compound $\mathbf{1 b}$ was converted to the corresponding $\mathrm{HONSu}$ ester, BocD-Dap(Z)-L-Ala-L-Val-L-Tyr(Me)-ONSu (2b), using HONSu and 1-ethyl-3-(3-dimethylaminopropyl)carbodiimide, and $\mathbf{2 b}$ was treated with trifluoroacetic acid (TFA) to give H-D-Dap(Z)-L-Ala-L-Val-L-Tyr(Me)-ONSu trifluoroacetate (3b-TFA). Cyclization of $\mathbf{3 b}$ unexpectedly yielded a mixture of the cyclic monomer and dimer in the ratio of $35: 45$, but the insoluble monomer, cyclo(-LAla-L-Val-L-Tyr(Me)-D-Dap(Z)-) (4b), was easily separated by washing with $N, N$-dimethylformamide in a yield of $28 \%$. Substitution of the amide bond for the ester bond resulted in a marked difference in the composition of the product.

The $\mathrm{Z}$ group in $\mathbf{4 b}$ was removed by treating $\mathrm{HBr}$ in $\mathrm{AcOH}$ (the poor solubility of $\mathbf{4 b}$, even in $N, N$ dimethylformamide, precluded catalytic hydrogenolysis of the $\mathrm{Z}$ group). The hydrobromide, cyclo(-L-Ala-L-Val-L$\operatorname{Tyr}(\mathrm{Me})-\mathrm{D}-\mathrm{Dap}-) \cdot \mathrm{HBr}(\mathbf{5 b})$, was treated with $\mathrm{CH}_{3} \mathrm{I}$ and $\mathrm{KHCO}_{3}$ in $\mathrm{MeOH}$ at room temperature for 1 day to give the desired cyclic monomer, cyclo(-L-Ala-L-Val-LTyr(Me)- $\triangle \mathrm{Ala}$-) (6b). Crude $\mathbf{6 b}$ was purified by silica gel column chromatography to give pure $\mathbf{6 b}(25 \%$ from $\mathbf{4 b})$; mp $259 \sim 260^{\circ} \mathrm{C}$ (dec.); MW, 416 (calcd. 416.2) (MW was determined on a Nihondenshi JMS-01SG-2 mass spectrometer). Compound 6a, cyclo(-L-Ala-L-Val-L-Amp$\triangle \mathrm{Ala}-)$, was synthesized in the same manner as for $\mathbf{6 b}$; 
yield of 6a from cyclo(-L-Ala-L-Val-L-Amp-D-Dap(Z)-), $27 \%$; mp $220 \sim 223^{\circ} \mathrm{C}$ (dec.); MW 444 (calcd. 444.2). Compounds $6 \mathbf{a}$ and $\mathbf{6 b}$ showed one spot each on TLC with several solvent systems and gave satisfactory results in elemental analysis.

Study by nuclear magnetic resonance spectroscopy. There are several differences between the ${ }^{1} \mathrm{H}$-NMR spectra (in DMSO- $d_{6}$ ) of $\mathbf{6 a}$ and those of AM-toxin I. The signals of the amide proton of the $\Delta \mathrm{Ala}$ residue in the lactam analog shifted downfield from $9 \mathrm{ppm}$ to $10.4 \mathrm{ppm}$. Two sets of signals with similar intensity were observed for the aromatic protons and $\beta, \gamma$-protons in the aliphatic side chains at $29^{\circ} \mathrm{C}$. These spectra turned to one set of the signals at $100^{\circ} \mathrm{C}$. These observations indicated that the lactam ana$\log$ exists as a mixture of two conformers with the similar populations. It should be noted that AM-toxin II is composed of two conformers with very unequal populations. $^{\text {7) }}$

Necrotic activity on apple leaf. The minimum toxic concentration of the analog $6 \mathrm{a}$ was $0.1 \mu \mathrm{g} / \mathrm{ml}$, whereas that of AM-toxin I was $0.002 \mu \mathrm{g} / \mathrm{ml}$. This means that the lactone ring in AM-toxin I is not indispensable for activity but is replaced by a lactam bond and accomplished with considerable loss of activity. This replacement simultaneously caused a marked change in conformer populations. The loss of activity might have resulted from a decrease in the population of the bilogically active conformer. Precise study on the conformation of $6 \mathbf{a}$ and $\mathbf{6 b}$ is in progress.

Acknowledgments. We thank Dr. K. Noda, Fukuoka Women's University, and Drs. H. Aoyagi, M. Waki, and S. Lee, Kyushu University, for their valuable discussions. We also thank Prof. T. Miyazawa and Dr. Higashijima, The University of Tokyo, for their discussions on conformation.

\section{REFERENCES}

1) T. Ueno, Y. Hayashi, T. Nakashima, H. Fukami, S. Nishimura, K. Kohmoto and A. Sekiguchi, Phytopathology, 65, 82 (1975).

2) Y. Shimohigashi, S. Lee, H. Aoyagi, T. Kato and N. Izumiya, Int. J. Pept. Protein Res., 10, 323 (1977).

3) Y. Shimohigashi and N. Izumiya, Int. J. Pept. Protein Res., 12, 7 (1978).

4) T. Kanmera and N. Izumiya, Int. J. Pept. Protein Res., 19, 79 (1982).

5) W. Meyer, L. Kuyper, D. Phelps and A. Cordes, J. Chem. Soc., Chem. Commun., 339 (1974).

6) A. Closs and R. Huguenin, Helv. Cheim. Acta, 57, 533 (1974).

7) T. Higashijima, T. Inubushi, T. Ueno and $T$. Miyazawa, FEBS Lett., 105, 337 (1979). 